\title{
Studying the Responsibility and Authority Limitations of Agent in Islamic Jurisprudence
}

\author{
Sayyed Hossain Vaezi (Ph.D.) \\ Assistant Professor, Department of Theology, Islamic Azad University, Isfahan (Khorasgan) Branch \\ Faculty of humanities and law, Islamic Azad University, Isfahan (Khorasgan) Branch, Isfahan, Iran \\ sh.vaezi@khuisf.ac.ir \\ Mohammad Ali Hossaini (M.A.) \\ MA in Criminal law and criminology: Islamic Azad University, Isfahan (Khorasgan) Branch \\ Faculty of humanities and law, Islamic Azad University, Isfahan (Khorasgan) Branch, Isfahan, Iran
} m.hossaini58@yahoo.com

\section{Doi:10.5901/mjss.2014.v5n9p583}

\section{Abstract}

This research has surveyed limitation of authority of agent and expression of its unknown and ambiguous aspects and answers questions hereof, with the purpose of reviewing power and responsibility limitations of agent by the method of qualitative analysis. Findings are: Responsibility of agent after the death of client, fault of agent and client's damages, limits in which agent in possessions and acts should observe client's interests, excess of granted authorities to the agent, contract of agency, responsibility in agent after death of client and generally agent's authorities. In Shiite jurisprudent opinion agent is considered depositary in the extents of agency contract and has no more responsibility and in the case of excess of the extents of agency, agent is responsible and Civil law also acknowledges this opinion. The extent of agent's authorities also include all authorities about legal procedures unless those which are excepted by client. These authorities include obligations which parties agree in advocacy contract.

Keywords: Agency, Agent, Responsibility, Civil Law, Contracts

\section{Introduction}

The extent of responsibility and authority of attorneys with current extended scope, is not justifiable in the narrow format of agency contract, because legal obligations which an attorney must comply with, according to special rules of advocacy and legal consultation, constitute a large amount of rules governing this profession so that legal specialist professionals have gradually exited out of region of private jobs and changed to juridical system dependents that in addition to bilateral contractual obligations toward client, they have to comply with rules and standards beyond content of advocacy contract for client and even for adverse party and juridical system and respective association. Accordingly, research about the extents of attorny's responsibility and authorites will help attorney society in leaving dejection and give it vitality.

Increasing development of effective role of specialist professionals in social positions of people, has made the belief skeptical that contractual obligation of attorney toward client is merely exercising necessary observations and attempting to offer a proper guidance to clients and he/she has civil immunity about inappropriate results and guidances, to the extent that different legal systems, have reduced the domain of this legal immunity by severance and classification of sevrices provided by attorneys, in many cases contractual obligations of an attorney are considered as commitment to result. For this reason, to efface the ambiguity and to obviation of the doubt along with expressing the legal nature and relations between attorney and client and detailed expression of legal services offred by attorney to clients, the sort of responsibility of attorney will be discussed.

In another word an attorney serves as a social mission to honestly bring facts up to courts about the client and to use facilities which society provides to establish the justice only in order to obtain legal purposes and in an ideal thought, see her/himself as a dedicated arbitrator beside judge who plays the role of umpire toward parties instead of reservation of fact and even within conquering client's right from adverse party, doesn't trespass principle of equity and toleration and doesn't comly with the dominant-beaten relation. 


\section{Legal Nature of Agency Contract}

Substancially, doubts in legal nature of agency rise where all of its legal aspects could not be justified with current and common definition about agency contract which is "vice-taking in possession". Because, although the attorney gains the right to defend client's right in special claim by his/her permission, but the substance of parties' agreement is to empower attorney to do such affairs which will likely result to conquer client's rights in related claim and the role of client's permission is only predosposing of exercising attorney's obligations. In another word, what is desired by parties to the advocacy contract related to file an action or responding to a claim, is not merely granting attorney to attend in court on behalf of client and to perform necessary defends so that, this relation could be considered as a kind of "vice-taking of possession" in the common meaning in implimenting other legal acts, rather, the intent of parties to such contracts is to undertake the attorney to utilize all legal skills in favour of client in prefering process for a specific amount of wage, so that existing legal relation is changed from a by-permission to an obligatory. (Ghahramani,2005:93)

\section{Issue of Agency}

The issue of agency, based on Art. 656 of Civil Law is to carry out an affair which is realized on behalf of another person and that affair is sometimes cerebral and mental, such as implimenting the formula of contract or unilateral obligation, as if it is usual and prevalent in marriage and divorce, sometimes is a material act with no need to intention of redact a contract which is cerebral and mental, and sometimes that affair is a cerebral and material act. (Imami,2012:328)

It is inferred from definition of famous jurisprudents about agency, "vice-taking in possession" that, delegation must be in such affair which produce some results with legal aspects for client and in their idiom, it must be "legal possession". Of course in this regard the level of agent interference differs, so that, may be it's only related to stating offer, or delegating deciding and negotiations about conditions of legal act. Only where the middleman is a factor of exercising order and noticing the intention -like postman in a contract between absents, or the officer of selling tickets to entrants, or consultation in legal or commercial affairs- the contract should not be entitled as agency. (Katouzian,2010:93)

\section{The Features of Agency}

Agency includes inherent features. Such that, is it binding or revocable, is it a contract or unilateral obligation, is it bypermission or not? which related summerised explanation is addressed here:

\subsection{Agency; as a kind of contracts}

In the topic of agency, the belief of famous jurisprudents is that agency is among contracts, because realiziation of agency depends on offer and acceptance which its right is realized by word and act and writing or beckon.

Seyed Muhammed Kazim Yazdi has criticized famous jurisprudent's opinion and said: Stronger opinion is that agency is not a contract but a unilateral obligation and, acceptance is not a necessity in it; because if \{a person\} for example delegates another person to sale his/her house and the latter practically carried out the act without acceptance, selling is done and valid. Allama Helli in "Ketab-e- Tazkerah" has expressed: The opinion that intrinsic consent is very acceptance is true; because finally has the force of unauthorised contract and in the case of lack of enforcement,it will not be valid.

As mentioned, there is disagreement between jurisprudents about whether agency is a contract or a unilateral obligation. Famous jurisprudents believe that agency is among contracts. Those jurisprudents who believe that agency is a unilateral obligation express that agency is merely a simple permission in possession and is realized by one party. But it doesn't need to other party's acceptance, and conclusion is that agency is among unilateral obligations. But, opponents ratiocinate that very act of the deputy person for example in selling the house is a sort of acceptance by act which is indicating the intent of the agent in accepting agency.

The conclusion is that agency is among contracts and requires offer and acceptance. But a group of Imamiyah jurisprudents following Allama Helli's thoughts, confirm that in realizing agency, intrinsic consent is enough ,and unlike other contracts, acceptance declaration is not needed. Of course what Allama Helli says in this regard that intrinsic consent is enough, does not comply with legal principles; because intrinsic consent without having intention and something purporting it could not be considered as "acceptance". (Lotfi, 2011:11-21) 


\subsection{Revocability or irrevocabilty of agency contract}

The agency contract is revocable toward agent and client. Therefore, each of them can void the agency in presence or absence of other party. Now, if the agent, deposes her/himself, the agency is utterly voided. But if client deposes the agent, invalidation of agency is provided to agent's knowledge of dismissal. So, according to the most accurate opinions, the agent is not deposed without knowledge of the dismissal. The meaning of knowledge here is delivery the new of dismissal to the agent by a person who his/her word is acceptable, although he/she is a righteous person and based on stronger opinion, for agent to be deposed, adducing witness about dismissal of agent by client is not enough. The client can depose the agent every time he/she wants, unless the contract of agency or not deposing the client is provided in addition to another irrevocable contract.(Amini \& Ayati, 2004)

Agency is a contract according to Art. 656 of Civil law, so offer and acceptance indicating agreement, intention and consent of parties are needed, for example a person gives a good to another for sale and he/she takes it over.

Famous jurisprudents believe that agency is a contract and Civil law has followed this opinion in this regard. The opinion of non-famous jurisprudents is that agency is not a contract but it's like a simple permisson and if it's done by offer and acceptance it's contract and to prove this theory they argue that when a person tells to another that I delegated you in selling my house and the latter sales the house, the sale is valid; although the seller is not aware of delegation and that the aforesaid act is the acceptance of agency, while if agency were a contract the sale would be ineffective because agency has not been constituted before the sale.(Imami,2012:325)

People's motive in selecting agent with no doubt, is to delegate him/her to defend their own rights, and because right of action is among rights about human freedom in society, as it's not possible to waive it, conceding the agency to another so that the client never can regain this right or personally apply it, is impossible. Perhaps this point is one of justifications for client authority in deposing the agent; because relying on revocability of agency for expressing the authority of client in deposing agent is not strong enough, because in some cases despite revocability of agency, abdication of agent has not any legal effects.(Ghahramani, 2005:95)

\subsection{Agency; a by-permission contract}

Some of jurisprudents, considered the agency in it's definition, as a mere permissin. (Tabatabaei Yazdi:666) Most commentators consider agency among by-permission contracts. (Imami,V2:239) With this meaning that as soon as realization of client's consent, agency is constituted and the agent is permitted in possession. However, agency is a revocable and by-permission contract, because no meaning can be infered other than revocation of agency from two phrases of deposition and abdication and revocability of agency, is a sentence which legislator has adapted from jurisprudence. By this research the objection brought up by Mohaghegh Naeini about division of contracts into bypermission and obligatory will be obviated. He believes that this division has low accuracy because the contract is very promise and in by-permission contracts there is not any promise. This objection would be acceptable if there were no difference between agency and mere permission; but, agency is granting delegation. But, procuration is founded on permission, so procuration in creation and continuity is based on permission and this, does not mean that agency is very mere permission. French lawyers beleive that the main reason of revocability of agency is parties' reliance to each other and they expect that each of them can revocate the contract.(Katouzian,2010:74)

\subsection{Effects of agency contract}

After conclusion of agency, the agent is envoyed to do financial and legal possession on behalf of client. These possessions are as follows:

1. Granting delegation: Client considers the actions of agent as his/her own action and grant the agent the authority of performing a possession on behalf of client (Lotfi,2011:6). Usually a legal act done by agent is on behalf of client, but sometimes client remains unknown: the contract is concluded for the account of client but in the name of agent, when a contracts in which the person transacts just in the account of another and in the name of him/herself, it should be regarded that it has the force of agency.

2. Performance of a legal act: The appearance of Art.656 of Civil law imply that the issue of agency may be a legal act such as selling a garden, leasing a house, resesion of a contract or a unilateral obligation, or a material act. It can be derived from Imamiyah famous jurisprudent's definition of agency ; "Vice-taking in possession" that: When the possession is legal the contract is agency and create some effects for client. But some commentators believe that the reality of agency is a contract which makes another person dominant to 
such possessions that is permitted for him/herself.(Katouzian,2000)

Some jurisprudents has opposed with famous jurisprudent's opinion in a different way that, agency is not basically a contract, but a unilateral obligation. According this viewpoint, agency will be permission to possession. However, it is understood from Imamiyah jurisprudents' qoutations that there are three viewpoints in definition of agency: famous jurisprudents believe that agency is "delegation in possession". Seyed KazimTabatabaei believes that agency is "granting permission in possession" and Kashif Al Ghata believes agency is " granting reign in possession".(Lotfi,2011:7)

\section{Agency in Islamic Jurisprudence}

Agency is one of confirmed contracts which was prevalent among people and the legislator has confirmed it after adding some qualifications. Some of jurisprudents have avoided to definite agency because of its clear meaning and some others has tried to provide a definition of agency containing external reality and juridical limits. Although these definitions are never a total logical one, because like definition of terms, are name description. Because agency has no actual substance so that a realistic definition could be offered.(Kheradmandi,2003:87)

\subsection{Agency in Shia jurisprudents' opinion}

Shia jurisprudents has different statements in definition of agency for example:

The author of the book Maghnaah, without presenting any definition of agency, has expressed special and general agency and stipulated to subrogation of agent on behalf of client in both aspects (Sheikh Al Mofid, Almaghnaah:816)

Also Sheikh Tousi in the book Mabsout, without offering any definition of agency and after explaining revocability of agency because of absence of any opposite qoutation in Islamic nation and also relying on narratives, has presented some cases in which agency is not allowed. He has also followed this policy in the book Annahayah (Tousi,V2:360). Ibn Hamzah in the book Alwasilah Ila Neil Alfdhilah believes that agency is conferment an affair to another for a reason; and he qualifies validity of agency to six conditions which one of them is that the client can delegate such affairs in which his/her own performance is valid. (Ibn Hamzak:282)

The author of Sharaea has provided a more accurate definition of agency saying: Agency is vice-taking in possession (Helli,V2:425). Most of next jurisprudents have also used this definition.

The author of book Javaher after construing agency as special vice-taking from juridical viewpoint also, in explaining qoutation of the author of book Sharaea that defines agency as vice-taking in possession, has not made any opposition and accept his opinion.( Najafi,V37:347)

The author of the book Miftah Al Keramah after meaning agency as vice-taking in possession, excludes bailment, farm letting and harvesting to agency because in non of these contracts possession is inherent purpose. (Hosseini Ameli,V7:522-523)

So, we can conclude that prediction of vice-taking possession to agency in in some of Shia jurisprudents' qoutation is indicating to vice-taking in possession inherently.(Kheradmandi,2003:88)

\subsection{Agency in Sunni jurisprudents' opinion}

Mavardi, one of jurisprudents of Shafei religion, says in definition of agency: Agency is putting agent in behalf of client which is practically permitted.(Hosseini Ameli,V7:522-523) The problem of this definition is having cycle, because the words agent and client are used in definition of agency. Regardless of this problem, the meaning of vice-taking in possession is also understood from this definition.

Ibn-e-Ghodamah one of famous jurisprudents of Hanbali religion without any definition of agency in his renowned book Asharh Alkabir,like Abdullah Bin Ghodamah in the book Almoghanni, represents the basic trait of agency with this statement: Delegation and acceptance of agency is not valid unless it is on behalf of a person who his possession in that stuff is valid. (Ibn-e- Ghodamah,V5:203) Because everyone who can possess by him/herself, absolutely can possess through delegation of deputy and everyone who his/her possession in something is valid, and that thing is capable to be deputed, it's valid to delegate a free or vassal, muslim or heathen person for that.

Abou Albarakat, one of jurisprudents of Maleki religion, without any definition of agency in the book Asharh-oIkabir, says: Indeed, agency is valid in any affair which is capable to be deputed, namely such affair in which performance by very person is not determined.(Abou Albarakat,V3:377)

Alaeddin Samarghandi a jurisprudent of Hanafi religion states : Agency is literally maintaining; such as God's language "God is enough for us and he is the good advocate" which 'advocate' here means protector. Sometimes the 
meaning of agency is 'handing over'; For example it is said : "I depended on God" which it means I devolved my affair to God. Juridical meaning of agency is similar to its literal meaning; devolution of possession and protection to the agent. (Samarghandi,V3:227) Regardless of objections made to noun explanation definitions, other jurisprudents of quadruplet Sunni religions have provided some same definitions for agency, for example:

The author of 'Kitab Al Fighh Ala Almazaheb Alarba'ah' in definition of agency in quadruplet Sunni religions' viewpoint qouting Hanafi jurisprudents has expressed: The agency means a person delegates another person in a right that the former can apply by him/her own without provision of delegation after death; and he narrates Hanafi jurisprudent's qoutation: Agency means a person delegates another in an allowable certain possession provided that the client is the owner of possession; and he describes Shafei jurisprudents' qoutation: Agency means a person devotes another person an affair so that he/she fulfills in lifetime of client, provided that the client is rightful in that affair and the affair is capable to be deputed; and also explains Hanbali jurisprudents' qoutation: Agency is, that a person who is permitted in possession deputes another person who is also permitted in possession in an affair that is capable to be deputed such as rights of God and mankind.(Jaziri,V3:145-146)(Kheradmandi,2003:90)

\section{The Features of Agency Contract in Islamic Religion's Standpoints}

The contracts are divided in terms of termination and obligation capability into two category; Irrevocable and revocable. An irrevocable contract is that none of parties can terminates it unless in cases which are determined by law. In contrast, a revocable contract is that each of parties in any time (he/she wants) can terminate it with no reason. Famous Imamiah jurisprudents have enumerated agency as a revocable contract. In this regard the principle of liberty of contract and juridical rule of "Contracts are subject to intents" can be relied on. About agency for example, parties can agree on irrevocability of contract by each one's wish.(Lotfi,2011:15)

Famous Imamiah jurisprudents have accepted the provision of agency in marriage contract or any other irrevocable contract. Quadruplet Sunni classes also alike Imamiyah jurisprudence, have considered delegation in contract as revocable. Some of these cases are mentioned:

1. Delegation in sale of pledge.

2. Adovocacy on behalf of absent client

3. Delegation in delivery of object to another in the absence of client

Revocability of agency also is inferred in Art. 1607 of Afghanistan's Civil law. Although revocability of agency is not stipulated in Iran's Civil law.

- Some of Hanafi jurisprudents believe that awareness of agent(of deposal) is a condition of agency validity.

- Some of Maleki jurisprudents believe that agency is one of revocable contracts. Each of parties can terminate it whenever they want unless in following cases:

In the case of advocacy in actions when the attorney participates in three hearing sessions. If agency is realized with consideration like permission, namely certain reward set up for a certain act or certain time, agency for consideration is concluded against consideration for contract of reward.

- Some of Shafei jurisprudents have described: Agency is not a irrevocable contract although it is conclude by formula of contract of reward, unless in two cases:

1. When abdication of the agent causes loss of client's property and accordingly his/her finantiol damage. In this case agency is irrevocable abdication of agent is not acceptable.

2. If agency is realized by the word of leasing with all conditions, it is irrevocable, and in other cases is revocable. Hanbali jurisprudents beleives that agency is revocable and they have explained: Each of parties to the contract can terminate the contract whenever time they want.(Lotfi, 2011:57)

\section{Comparative Studying of Agency in Islamic jurisprudence and Religions}

Ammah jurisprudents have divided delegation cases into two categories:

A. Cases in which delegation is valid.

B. Cases which are not capable to be delegated.

Although they have some objections in its instances which some of them is mentioned in continue:

\subsection{Delegation in God's right for proving the right:}

Sometimes God's right -which are some penances that proving of them has been devolved to judge and they don't 
require any claiment capable to be delegated- such as penance of adultery and drinking alcohol that in such cases, the judge sentences with no need to action with probative evidences such as testimony, clear evidence and confession and delegation in these cases is not allowable.

Sometimes the subject of penance (God's right) is such that needs claim to be posed, such as penance of thievery and defamation that in these cases in religion of Hanafi , proving the penance is performed in two forms: a- Delegation in proof. b- Testimony, clear evidence and confession.

Abou Yousef believes that in the second form also the claim is not provable excepting through clear evidence and confession, and delegation herein is not allowable.

This disagreement is observed about retaliation. Because for the second theory ( Abou Yousef's opinion) it is argued that irrevocability of agency in performing the right of retaliation, is also true about proving retaliation right based on analogy, because proof is considered as a mean of performance.

Abou Hanifah in opposition to this argument says: There is much difference between these two topic (proof and performance), because prohibition of deputation in performance is due to uncertainty and this uncertainty is not true about proof.

Shafei jurisprudents believe that irrevocability of deputation in proving God's right is because that, the right, here is for God, and he has ordered elimination of punishment in the case of uncertainty. Deputation is a cause for emphasis of exigency of penance, but, about retaliation and penance of defamation and thievery, deputation could be allowable, since in these cases there is a kind of mankind's right which it is capable to be deputized.

Hanbali jurisprudents believe that substitution in proving retaliation and the penance of defametion is allowable whether or not the client is present, becasue these two cases are of mankind's rights and the need of substitution in these rights is obvious and indisputable. The story is same about special penance to God's right such as penance of adultery and thievery, since, also in these cases substitution in proving is allowable and prophet Muhammad (PBUH) constituted Anis in proving and performance of penance of adultery and said: "She confessed and [Anis] stoned her to death".

The objection brought up in this case that, it won't be possible to apply the rule of 'elimination of penances' , is now reprobated because the agent can apply the rule ' Penances are eliminated by uncertainties ' in due cases as client's deputy.

\subsection{Substitution in performance of God's right:}

Jurisprudents of quadruplet religions are agree that the judge can hand over the performance of divine penances and also retaliation to another so that he/she performs the penances as agent on behalf of the judge, provided that the client is present in the time of performance, so substitution is allowable in these cases. But some cases in which bringing action is not needed and has been determined in law, The judge is responsible for performance of such cases.

Abou Yousef says substitution in performance of penance is not allowable, because performance of penance on a assassin is among God's right which must be performed by judge and in some case such as penance of defamation and thievery is not allowable in performance, as substitution in proving of penance, and content of this word is lack of permission of substitution in both cases of requirement and absence of requirement of bringing action. There is disagreement among Hanafi jurisprudents about some cases in which the person who is subject to defamation and the person whose property is stolen are absent. Some of them consider substitution allowable also in this case, since, uncertainty of elimination of penances is not performable and performance is after sentencing of the judge and remission of person who is jubject to defamtion or whose property is stolen, or their presence or absence has not any effec in performance of penance. Yet, quadroplet religions consider that in performance of discretionary punishment awarded by judge substitution is allowable, because this kind of punishments imply a personal right and the rule of 'elimination of penances by uncertainty' is not applied here.

Maleki jurisprudents believe that substitution in performance of punishments is allowable in the presence or absence of client.

Hanbali jurisprudents also consider substitution allowable in both cases, but some of Hanbali jurisprudents like Hanafis believe that performance of retaliation and the penance of defamation are not allowable in the absence of client.

Shafei jurisprudents believe substitution in performance of the penance belonging to human, such as retaliation and the penance of defamtion like another mankind's rights is allowable and in some case such as the penance of defamation it is obligatory and there is no difference between the case of presence or absence of client in this regard. 


\subsection{Substitution in mankind's rights}

Substitution in mankind's rights such as performance of debts and undertakings other than retaliation and defamtion, and in both phases of proof and performance is allowable and Sunni jurisprudents' reason is people's requirement to substitutions in this regard.

There are some disagreements in this topic:

a. Hanafi jurisprudents have provided the permission of substitution to the adverse party's consent in the case of absence of client in hearing session, unless the client can not show up because of illness, journey, inability in bringing action, woman's veil, having excuse for presence in session and so on.

b. Maleki jurisprudents have not considered substitution allowable when hearing takes long more than three sessions, unless in the case of excuses.

c. Hanbali jurisprudents believe that substitution in mankind's right is allowable provided that at least the agent is not aware that the client is ruthless.

\subsection{Substitution in testimony:}

Since the nature of testimony is notifying about something that the person has seen or heard and this affair is possible only for bystander and listener, Sunni jurisprudents together believe that substitution in testimony is not allowable.

\subsection{Substitution in confession:}

Hanafi,Maleki and Hanbali jurisprudents beleive that substitution in confession is allowable, but Shafei jurisprudents consider confession as a notification of right and they believe that substituting in that is like substituting in testimony.

But, substitution in paying the debt, quittance, marriage, releasing from marriage tie obtained by wife upon payment of compensation, conveyance in donation, alms, barrowing, mortgage, deposit, accepting of donation, partnership, prest, divorce, lease, tenancy, sale, advanced sale, sale of coins against others coins is allowable and no disagreement is seen in this regard. (Amid Zanjani, 2003,:219-223)

\section{Responsibility of Agent in Jurisprudence}

Shia jurisprudents' opinion is that agent is depositary acting in the extent of agency contract and has no responsibility, unless in the case of trespassing the extent of agency.(Kheradmandi, 2003:204)

Ibn-e-Joneyd believes that in the latter form agency is also null, but other jurisprudents believe that trespassing extent of agency although causes agent's responsibility, but it doesn't cause nullification of the contract and pertinence of the principles of application is permanence of agency. (Helli, V6:37)

So, if possessions of agent are done in the extent determined by client, are true and in the case of trespassing that extent, it is null, but the agency remains valid.

Match or mismatch of agent's possessions with this extent, sometimes can be understood from words, and sometimes by circumstantial evidences attached to it so that generalization of the word indicates that. (Helli, V2:120)

Mohaghegh Khorasani, after qouting this sentence of Allamah Helli in the book 'Tazkerah', considers it as one of conditions of agency contract and notes that the agent can not transgress what client has determined, unless, circumstantial evidences imply client's intent and consent, or custom behalf it. Then, regarding to this principle says that: 'If client permits the agent to forward sale and the client sales pecuniary, or if client determine a certain price but the agent sales the good more than that price, these cases are absolutely in the confine of client's permission and custom also emphasizes it. Of course, these situations are provided to agent's lack of information about client's intetion of determination of the special case, otherwise, the agent is not permitted to transgress '.(Bohrani,V22:64)

One of Shafei scientists consider validity of possessions accordant to client's permission and nullification of possessions against that permission among features of agency. Identifying of this accordance is possible sometimes through words and sometimes through circumstantial evidence. He continues stipulating that the agent must pay attention to limitations determined by client and observe its meaning according to custom. Afterwards, noting that possession of agent is depositary and the agent has no responsibility acting according to issue of agency, (whether agency is free or with consideration), he stipulates that in the case of trespassing of agent, he/she is responsible, and responding to the question whether after realization of trespass, the agent is deposed or not , he expresses two aspects:

According to the first aspect, he considers agent deposed and according to second aspect which he treats it more 
accurate, he sentences to permanence of agency. With this argument that the contract has given a permission to agent and safekeeping is a feature applied to it, so with elimination of this feature, the original contract should not be necessarily null. (Rafei, V11:26,46,60,61)

Regarding to what is proposed, and reffering to other Sunni and Shia jurisprudent's quotations, it is clear that in the case of agent's trespass, although he is responsible, but the contract is not terminated. On the other hand, in the topic of agency, when jurisprudents have wanted to express termination factors of contract, they have not mentioned to agent's trespass as one of these factors. (Kheradmandi,2003:204-205)

\section{Conclusion}

Respecting to findings of these research, delegation in actions, because of specific nature and pertinence, especially because of its relevance to rules related to procedural system, is not definable in a simple bilateral relation between agent and client. Because of that, the necessity of government's supervision to this legal entity and necessarily encating special rules for a good relation between parties and securing their legal rights and determinig some duties for agent, in addition to those which parties have agreed on in bilatreral contracts, has been sensible since long time ago.

It should be noted that the agency, since past centuries, has been proposed as a profession rather than a simple bilateral legal and contractual relationship and with turning procedural systems into some complicated new systems, this profession has been considered as a legal tool in securing and preservation of personal rights in society on the one hand, and on the other hand for performance of justice.

Also in Iran, in second chapter of the Law of Organization of Justice 1928, for the first time, advocay was governed by a special rule. Enactment of so called laws confirms that extensive and complicated relationship between agent and client in a claim was not included in the format of special preset contracts and at least the necessity of supervision and control to this profession has necessitated that, some responsibilities more than those which are for agent in agency contract should have been set up. So, limitations of duties and responsibilities of agent must be determined based on special law on agency, and the ground of Civil law in the topic on agency contract should be used in the case of silence of special law. In another word, the relationship between attorney and client should be considered as a branch which its relation to the sturdy body of agency contract is mere a connecting relation so that it could be said that, without conclusion of agency contract; the attorney has no undertaking against client. So, no one can repudiate that relationships between parties is a contract. But this note should be believed that one of effects of contracts adjusted based on Advocacy Law 1936 and its regulations, is that an attorney, in addition to contractual obligations of agency, has implicitly accepted obligations determined by Advocacy Law 1936. For this reason, violation of rules predicted in Advocacy Law and its regulations has the force of contractual infraction and in another word, duties determined by law, are legal requirements for lawyers.

For this reason, although agency is among revocable contracts and the agent can abdicate whenever he/she wants, in advocacy, the attorney has not such general authority and infracting this rule will cause him/her responsible. According to Art, 36 of Advocacy Law, if the attorney wants to abdicate, he/she must primarily notify the client and the court in a way that the client can appoint a new attorney and introduce him/her to the court.

The main attorneys' duty is offering assistances to implement justice. In creation of the profession of attorney ship, among loyalty, trusteeship and client confidentiality and the duty of assisting performance or justice some conflictions is occurred. To resolution this conflict in these cases, if possible, the attorney dissuades the client of pursuing the action and otherwise he/she abdicates so that he/she doesn't prevent performance of justice contrary to his/her main duty, and has not to decelerate some information that he/she completely knows that they are false or wrong.

\section{Resources}

The Holy Quran

Abou Albarakat, AlSharh Alkabir, Volume 3

Ameli, Seyed Mohammed Javad Hosseini, Meftah Alkeramah, Volume 7

Amid Zanjani A. 2003. An Introduction to Islamic Comparative Law. 1st Edition. Tehran: Mizan Publications

Amini A, Ayati M, 2004, Feghh-e-Estedlali, 7th Edition, Qom, Ketab-e-Taha Publications

Bohrani, Mouhaghegh, Al Hadaegh Alnazerah, Volume 22

Emami, Seyed Hasan, 2012, Civil Law, 24th Edition, Tehran, Islamiah Publications

Ghahramani N. 2005. Civil Liability of Attorney. 2nd Edition. Tehran: Gandom Publications

Helli, Allamah, Mokhtalef Alshia, Volume 6

Helli, Allamah, Tazkerat Alfoghaha, Volume 2 
Helli, Mouhaghegh, Sharaye'a Alislam, Volume 2

Hosseini Ameli, Seyed Mohammad Javad, Meftah Alkeramah, Volume 7

Ibn-e-Ghodamah, AlSharh Alkabir, Volume 5

Ibn-e-Hamzah, Alvasilah Ela Nail Alfazilah

Jaziri, Abd Arrahman, Alfeghh Ala Almazaheb Alarba'ah, Volume 3

Katouzian N. 2000. Civil Law, Special Contracts 4. 6th Edition. Tehran: Sahami Enteshar

Kheradmandi, s. 2003, Agency In Commercial Law and Its Comparison With Jurisprudence, 1st Edition, Qom, Institution of Boustan-eKetab

Lotfi A. 2001. Range Of Juridical-Legal Discussions bout Agency Contract. 1st Edition. Tehran. Javdane,Jangal Publications

Mavardi, Mohammed Bin Habib, Alhavi Alkabir, Volume 6

Mofid, Sheikh, Almaghna'ah

Najafi, Mohammad Hasan, Javaher Alkalam, Volume 37

Rafei, Abd Alkarim Bin Mohammed, Fath Alaziz Fi Sharh Alvajiz, Volume 11

Samarghandi, Tohfat Alfoghaha'a, Volume 3

Tabatabaei Yazdi, Seyed Mohammed Kazem, Orvat Alvothgha

Tousi, Sheikh, Almabsout, Volume 2 